\title{
NARRATIVES OF STAKEHOLDERS UNDER THE PERSPECTIVE OF THE STRATEGY AS SOCIAL PRACTICE
}

\author{
JOSÉ B. S. NETO \\ (iD) https://orcid.org/0000-0003-4518-1960 \\ JACQUELAINE F. BORGES ${ }^{2}$ \\ (iD) https://orcid.org/0000-0001-8550-8329
}

To cite this paper: Souza Neto, J. B., \& Borges, J. F. (2019). Narratives of stakeholders under the perspective of the strategy the social practice. Revista de Administração Mackenzie, 20(1). doi:10.1590/ 1678-6971/eRAMR190118

Submission: June 12, 2018. Acceptance: July 31, 2018.

\footnotetext{
1 Universidade de São Paulo (USP), Ribeirão Preto, SP, Brazil.

2 Universidade Federal de Uberlândia (UFU), Uberlândia, MG, Brazil.
}

\section{(cc) BY




\section{ABSTRACT}

Purpose: The paper is driven by the following question: how do interest group narratives contribute to the dialogue between the perspective of strategy as a practice and the stakeholder theory? The objective is to analyze the changes, permanent and tensions in the narratives of the stakeholders, seen the strategic practices, in the context of mining.

Originality/value: Strategy as a social practice concerns the relationships between organizations, individuals and society in search of coexistence. This study establishes a dialogue between strategy as a social practice and the political perspective of the stakeholders, considering that they interact in networks, seeking the creation of value from mutuality.

Design/methodology/approach: Field research was conducted in a qualitative and longitudinal approach. Data collection used to document research techniques in notes and videos of public hearings, newspaper research and interviews.

Findings: The results show narrative interactions of six interest groups: entrepreneurial organizations, public authority, education, environment, residents of the area of implantation and the productive sector. The result suggests a relevant role of relational tensions as elements that restrict and enable changes and permanent and indicate the dynamic nature of intra and intergroup interactions of stakeholders. The proposed theoretical dialogue extends the field of strategic studies, in a postmodern dimension, by establishing a dialogue with the political side of stakeholder action as an alternative to the traditional functionalist perspective in the field.

\section{KEYWORDS}

Strategy as practice. Stakeholder Theory. Narrative research. Mining sector. Relational tension. 


\section{INTRODUCTION}

The State of Minas Gerais is considered by the Brazilian Mining Institute (IBRAM) (2015) as the most relevant to the mining industry. Minas Gerais moves $53 \%$ of the mineral sector. Of the 100 largest mineral extraction mines, 40 are in that state. Of the ten largest mining cities of Brazil, seven are in Minas Gerais. Of the 853 municipalities of Minas Gerais (Brazilian Institute of Geography and Statistics [IBGE], 2010), 400 have mineral extraction activities, being the largest producer of gold, iron and phosphate of the country, and the largest producer of niobium in the world (IBRAM, 2015).

This phenomenon also occurs with phosphate mining, a central component for the production of fertilizers, which in turn, is crucial and strategic for the increase of productivity in Brazilian agricultural activity and its economic support. According to the National Department of Mineral Production (DNPM) (2016), which was transformed into the National Mining Agency in 2017, the phosphate mining, the basis for fertilizer production, is insufficient to meet the internal demand of the country. The report highlights the deposits that may come into operation, among these, "one of the most promising is from Patrocínio in Minas Gerais" (DNPM, 2016, p. 71). Therefore, the theme of this research is relevant to the State of Minas Gerais and Brazil.

The process of deploying a mineral extraction company involves various social interactions between various individuals and interest groups. As an economic and social activity, mining enables the formation of enterprises that generate expectations, mobilize interests and meet the needs of various stakeholders: entrepreneurs, environmentalists, suppliers of goods and services, representatives of the Government, students and members of the productive sector. These groups are a fundamental dimension of the implementation of an enterprise in the mining sector.

This article is driven by the following question: How do the narratives of interest groups contribute to the dialogue between the perspective of strategy as a practice and the theory of stakeholders? The goal is to analyze the changes, the permanence and the tensions in narratives of the stakeholders, seen as strategic practices in the deployment process of a phosphate mining plant. Stakeholders are defined as those that influence or are influenced by a particular organization in the pursuit of their goals (Freeman, 1984; Donaldson \& Preston, 1995; Clarkson, 1995). This study establishes a dialogue between strategy as a social practice and a political perspective of stakeholders, since strategy as a social practice, regards the 
relations between organizations, individuals and society in search of their coexistence.

The stakeholders may be perceived differently by organizations, depending on how they interact, according to Bridoux and Stoelhorst (2014). In a socio-political approach of the stakeholders, Sachs and Rühli (2011) defend mutual value creation through network actions. Bonnafous-Boucher and Rendtorff (2016) establish a relationship between the business world and public life, making a civil society a stakeholder society, given the complexity of the environmental organizations, including the economic and legal, social, political, cultural and ecological aspects.

The concepts of strategy as a practice and strategic practices used in this article originate from the perspective of strategy as practice (ECP) (Jarzabkowsky, 2003, 2004; Whittington, 1996, 2003, 2006) and on the assumption that the dynamic interactions of interest groups and their practices can also exert influence on the results of a given phenomenon (Dias, Rossetto \& Marinho, 2017).

The dialogue between these two perspectives - strategy as a social practice and stakeholders - is conducted as a narrative. For Jones and Wicks (1999), narratives relate to what organizations should do from an ethical perspective and the instruments they use to achieve their goals. The importance of language and narratives in organizations is analyzed by Oliveira and Bulgacov (2013). Brown and Thompson (2013) claim that there is a natural relationship between narrative and strategy as a practice. Barros and Carrieri (2015) claim that studies of narratives based on history are important, as these can enhance the visibility of practices based on the experiences of the practitioners. Vaara, Sonenshein, and Boje (2016) argue that the narrative is able to promote stability or change in organizations. From the epistemological and methodological point of view, Clandinin and Connelly (2000) show that the narrative is interested in the lives of people, the way lives interact with other lives and develop the experiences.

In three distinct sections below, each of the three themes will be addressed: strategy as a practice, interest groups (stakeholders) and narratives. The methodological procedures are described in their own section. The next section describes and analyzes the results of the research of the narratives of the stakeholder interactions in the process of deploying a phosphate mining plant, located in the municipality of Patrocínio, in Minas Gerais. The paper ends with a section of conclusions and implications of the research. 


\section{THE PERSPECTIVE OF STRATEGY AS A SOCIAL PRACTICE}

In the early 2000s, studies that embraced and helped to spread the concept of SAP (Strategy-as-Practice), like Johnson, Melin and Whittington's (2003), proposed the need for research in strategy to dedicate more attention to the day-to-day activities of organizations, giving emphasis on details, which were called micro activities. For Wilson and Jarzabkowski (2004), the traditional perspective of strategy is insufficient and limited if what is desired is to understand how strategy arises and how it is put into practice by its practitioners in the organizational environment.

When the strategy is not widespread in the structure and people do not have access to it, that might promote contradictions whose mediation contributes to change, says Jarzabkowski (2003). These two aspects, permanences and changes, are important themes in the SAP universe, which Jarzabkowski (2004) referred to as recursion and adaptation, and assigned factors that favor permanences and changes (Figure 2.1).

\section{(Figure 2.1)}

\section{FACTORS THAT FAVOR PERMANENCES AND CHANGES}

\begin{tabular}{|c|c|c|}
\hline Contexts & $\begin{array}{l}\text { Recursive Factors that favor } \\
\text { permanences }\end{array}$ & $\begin{array}{l}\text { Adaptive Factors that } \\
\text { favor changes }\end{array}$ \\
\hline $\begin{array}{l}\text { Macro } \\
\text { Context }\end{array}$ & $\begin{array}{l}\text { Completely institutionalized structures; } \\
\text { Dominant social structures; } \\
\text { Stable Economic and normative } \\
\text { regulation; } \\
\text { Stable competition. }\end{array}$ & $\begin{array}{l}\text { Markets with rapid growth; } \\
\text { Saturated or mature markets; } \\
\text { Institutionalized social structures; } \\
\text { Pluralism in social structures; } \\
\text { Changes in economic and social } \\
\text { regulation and standards; } \\
\text { High competition. }\end{array}$ \\
\hline $\begin{array}{l}\text { Micro } \\
\text { Context }\end{array}$ & $\begin{array}{l}\text { Highly political; } \\
\text { Fragmented and discrete subcultures; } \\
\text { Homogeneous communities; } \\
\text { Unique and strong culture; } \\
\text { Dominant logic; } \\
\text { Bureaucratic, specialized, hierarchical } \\
\text { and structure; } \\
\text { A strategy built on the top-down model; } \\
\text { Strong operating routines; } \\
\text { Low absorption capacity. }\end{array}$ & $\begin{array}{l}\text { Several practice communities; } \\
\text { Social interaction between communities; } \\
\text { Entrepreneurship; } \\
\text { Domestic investment initiatives; } \\
\text { Peripheral involvement strategies; } \\
\text { Distribution and transfer of knowledge; } \\
\text { Non-hierarchical, cellular and networked } \\
\text { structures; } \\
\text { Structures based on flexibility and } \\
\text { change codes (patch) }\end{array}$ \\
\hline
\end{tabular}

(continue) 


\section{(Figure 2.1 (conclusion))}

FACTORS THAT FAVOR PERMANENCES AND CHANGES

\begin{tabular}{|c|c|c|}
\hline Contexts & $\begin{array}{c}\text { Recursive Factors that favor } \\
\text { permanences }\end{array}$ & $\begin{array}{l}\text { Adaptive Factors that } \\
\text { favor changes }\end{array}$ \\
\hline $\begin{array}{l}\text { Actor } \\
\text { perception }\end{array}$ & $\begin{array}{l}\text { Assimilation narrow structures; } \\
\text { Reflective capacity low; } \\
\text { Accommodation zone of restricted } \\
\text { interest; } \\
\text { Skills, abilities and knowledge } \\
\text { base low. }\end{array}$ & $\begin{array}{l}\text { Wide assimilation structures; } \\
\text { High reflective capacity; } \\
\text { Accommodation area of broad interests; } \\
\text { The basis of competencies, skills and } \\
\text { vast knowledge. }\end{array}$ \\
\hline
\end{tabular}

Source: Adapted from Jarzabkowski (2004, p. 539).

SAP addresses the interactions between people in a given context and how the strategy is built. For Chia and MacKay (2007) and Chia and Rasche (2010), SAP is built as social activity and it reorients strategy for the practices developed by the actors, what they do, how they communicate, and how they use their competence in favor of the goals of the organization.

One of the key elements for understanding SAP is the integration between practice, praxis and practitioners. As presented by Whittington (2006), practitioners are strategists who "develop, shape and run" strategy, which may be inside or out of the Organization as external consultants, advisers and what the author calls strategy "gurus" (p. 619). According to Jarzabkowski and Spee (2009), praxis is defined as a flow of activity that interconnects the micro-actions of individuals and groups with broader institutions in which these actions are located and to which they contribute. The basis and references of the praxis are the organization's practices, which are the routines that may or may not be institutionalized.

Key elements for SAP are strategizing and organizing. For Walter and Ahmed (2011), strategizing regards the activities of various actors and the way in which these activities are carried out. In different, dependent and independent ways (Light \& Walter, 2015), strategizing refers to the action of building strategic practices, and organizing refers to the action of building the organization as a whole, its goals, interests and image. Strategizing and organizing emphasize movement.

Regarding pluralistic contexts, which mark the occurrence of SAP in complex environments, Denis, Langley and Rouleau (2007), Jarzabkowski, Lê, and Van de Ven (2013), Pascucci and Meyer (2013) denounce the implications to strategy the moment intentions become actions. For these 
authors, in complex and pluralistic environments, the cognitive elements of each of the practitioners are crucial to the construction of strategy, so ambiguity and difficulty of consensus press organizing and strategizing.

The open concept of strategy considers aspects comprehensively, which accommodates the experiences and interactions among these practitioners, and is called by Hautz, Seidl, and Whittington (2016) Open Strategy, defined as the open movement of strategy that promises to increase transparency and inclusion, involving stakeholders both internal and external to the organization.

\section{THE STAKEHOLDERS PERSPECTIVE: FROM FUNCTIONALISM TO A POLITICAL CONCEPT}

In the field of studies on stakeholders, a functionalist concept emerged in the early 1980s. According to Freeman (1984) and Freeman, Harrison, Wicks, Parmar and De Colle (2010), this theory was designed to help organizations solve three problems: 1 . The generation and exchange of values; 2 . Better understand the relationship between ethics and capitalism in organizations; and 3. Help managers change their perceptions about the creation of value and ethics in changing environments. Savage, Nix, Whitehead and Blair (1991), Mitchell, Agle and Wood (1997) and Macharia, Alves and Raposo (2012), in their time, classify stakeholders differently but regard them relevant to organizations and deserving their consideration.

The way in which interest groups may be perceived by the organizations is determined by how they interact, according to Bridoux and Stoelhorst (2014). Their interactions may be perceived as reciprocal or motivated by self-interest. The fair approach is the beacon used by the authors for this analysis of reciprocity, while the self-expansion approach is used in dealing with those stakeholders with high bargaining power.

In this respect, Bonnafous-Boucher and Rendtorff (2016) argue that the principle of the theory of stakeholders is the same as that of civil society, i.e., individuals seek primarily their own well-being and the satisfaction of their needs. According to these authors, the scope of these interests is in line with the common good and that is why they are mediated by the interests of the collective. The individual interest must coexist with the collective interest. This occurs through the institutionalization of interests, or through the formation of groups (of interest) that are governed by internal rules and legality (Bonnafous-Boucher \& Rendtorff, 2016). 
The prospect of generating value for organizations is latent in the traditional view of the theory of stakeholders, as formulated by Freeman (1984) and Freeman et al. (2010), putting the organization at the center of the activities. A contribution of this theory in the field of social and political philosophy has not been explored, as argue Bonnafous-Boucher and Rendtorff (2016), for whom "the construction of public life, the common good, the art of living together has no center and, if in fact there is such a center, it has no nothing to do with the economic life "(p. 53).

Organizations are not able to cater to all stakeholders, and so they need to negotiate, generating tension. Bonnafous-Boucher and Rendtorff (2016) argue that a spread of interests of the groups is difficult to identify, as well as their influence and needs in a global context; such aspect competes to maintain conflicts between stakeholders. This approach differs from the traditional functionalist approach, advocated by Freeman (1984) and Freeman et al. (2010).

A political perspective of the theory of stakeholders opposes a functionalist approach, strongly based on economic assumptions and the unique role of the stakeholders to the economic performance of the company. As advocate Sachs and Rühli (2011), a difference of the political perspective is the focus on mutuality which ensures that values are created with and for stakeholders, diverging from the position of value created solely on the basis of economic purposes, as a capital return.

In a social and political perspective of the theory of stakeholders, in contrast to an economic perspective, the groups and their representatives do not have as an exclusive focus the overcoming or elimination of barriers in their contexts of action for the achievement of their economic interests. The stakeholders mobilize other experiences, in addition to the economic one, considering the dynamism of goals, expectations and needs of the networks with whom they interface and act in different networks simultaneously. In this way, a network of stakeholders, rather than being perceived as, for example, competitors, can be assumed to be a contributor network, no longer perceived as restricting their practices to an extended position in the generation of value (Sachs \& Rühli, 2011).

\section{NARRATIVES SEEN AS STRATEGIC PRACTICES AND STAKEHOLDERS: A DIALOGUE}

In a study of the narrative as an epistemological and methodological issue, Clandinin and Connelly (2000) examine the tensions, the confrontation 
between the narrative thinking and the dominant narrative, and the border that exposes tension points as: 1 . Temporality - everything has a past, a present and, implicitly, a future; 2 . People - people are in a continuous process of change and are relevant to the phenomenon that is observed; 3 . The action - seen here as a narrative symbol; and 4 . The certainties events in a narrative perspective can always have another meaning. All these elements of tension are interconnected and immersed in 5. Contexts that are crucial to giving meaning to each of the individuals or groups.

In organizational studies and in the field of strategy, the narrative is the means by which organizations can be understood, says Czarniawska (2007). The narratives allow "understanding of how humans build sense, building experience, knowledge and identity", claim Fenton and Langley (2011, p. 1174). The strategy is a process of the relationship of power that is exercised "in an ambiguous and contradictory way; while it supports, it frustrates" (McCabe, 2009, p. 152). Ambiguity is inherent to the management process and contravenes clarity because when managers manifest themselves ambiguously, they avoid resistance giving more power of interpretation to their interlocutor, whereas if they are clearer, they become more responsible for the strategy (McCabe, 2009).

The existence of a natural relationship between narrative and strategy as practice is proposed and analyzed by Brown and Thompson (2013). The authors identify and analyze two reasons for this study: polyphony and equivocality. Polyphony refers to the dissonance in the understanding and dissemination of the key strategies of the organization; and equivocality, or ability to generate misunderstandings, is present in complex relationships generated by strategy as a social practice. The approach of the study of narrative allows those nuances to be identified. Brown and Thompson (2013) understand that strategies are reflections of power and are through the power that dominant strategies can be replicated.

Studies of narratives based on history can broaden the visibility of practices based on the experiences of practitioners, which Barros and Carrieri (2015) claim to be important and call ordinary management. The narrative is able to promote stability or change in organizations, argue Vaara et al. (2016, p. 17). These authors recognize that this concept connects to polyphony and multiple interpretations, proposed by Brown and Thompson (2013). Vaara et al. (2016) realize that, given the complexity of change, a single narrative would not be able to understand all of its nuances.

Human action unveils a strategy as a social practice and it is through the narratives that this happens, because they enable the understanding of polyphony, that the strategy in this approach brings out, claim Rese, Kuabara, 
Villar and Ferreira (2017). These authors explore the issue of sensemaking (construction of meaning) and sensegiving (interpretation of the meaning) as the construction of meaning mediated by the narratives of the practitioners.

In Figure 4.1, we present a proposal for a set of attributes of the narratives (one to eight). In a given context (6), stakeholders/practitioners (1) spark the narratives (4) when interacting (5) in defense of their interests or in the fulfillment of their strategic practices. This interaction can generate tensions through ambiguity (3), polyphony and equivocality (7). The manifestations of power (2) can occur in an attempt to establish a dominant narrative, be it to promote change or permanence. The narratives are also generated in the relations between the groups/practitioners with society (8) from a political perspective.

In the political perspective of stakeholders, analyzed by BonnafousBoucher and Rendtorff (2016), the approach of the theory of stakeholders interfacing with strategy allows practitioners the recognition of those involved as well as their needs, their interests and their (pre)dispositions, facilitating the identification of opportunities for the generation of higher value, with the creation of interaction networks (Sachs \& Rühli, 2011), which triggers the process of negotiation by means of licenses.

\section{(Figure 4.1)}

DIALOG BETWEEN STRATEGY AS PRACTICE AND A POLITICAL
PERSPECTIVE OF STAKEHOLDERS

\begin{tabular}{|c|c|c|c|}
\hline $\begin{array}{c}\text { Items/ } \\
\text { Identification }\end{array}$ & Narrative Attributes & $\begin{array}{l}\text { Political perspective of } \\
\text { stakeholders }\end{array}$ & Strategy as Practice \\
\hline 1 & Narrative actors & $\begin{array}{l}\text { Stakeholders: internal and } \\
\text { external groups and } \\
\text { individuals. } \\
\text { Act in defense of their } \\
\text { interests. }\end{array}$ & $\begin{array}{l}\text { Practitioners: individuals and } \\
\text { intra-organizational and } \\
\text { non-organizational groups. } \\
\text { Experience strategic } \\
\text { practices. }\end{array}$ \\
\hline 2 & $\begin{array}{l}\text { Power to convince } \\
\text { and be convinced }\end{array}$ & $\begin{array}{l}\text { Influence. } \\
\text { Enforce their prerogatives } \\
\text { to achieve their interests. } \\
\text { Motivations }\end{array}$ & $\begin{array}{l}\text { Practice. } \\
\text { Acts as a referential source } \\
\text { that limits and enables. The } \\
\text { diffusion of power } \\
\text { contributes to ambiguity. }\end{array}$ \\
\hline 3 & Ambiguity & $\begin{array}{l}\text { Similarities and differences } \\
\text { in motivations, resource } \\
\text { property and perceptions } \\
\text { (clear or ambiguous) of } \\
\text { other groups. }\end{array}$ & $\begin{array}{l}\text { Multidimensionality of } \\
\text { practices: behavioral, } \\
\text { cognitive, moral, cultural, } \\
\text { political, economic, etc. }\end{array}$ \\
\hline
\end{tabular}




\section{(Figure 4.1 (conclusion))}

\section{DIALOG BETWEEN STRATEGY AS PRACTICE AND A POLITICAL PERSPECTIVE OF STAKEHOLDERS}

\begin{tabular}{|c|c|c|c|}
\hline $\begin{array}{l}\text { Items/ } \\
\text { Identification }\end{array}$ & Narrative Attributes & $\begin{array}{l}\text { Political perspective of } \\
\text { stakeholders }\end{array}$ & Strategy as Practice \\
\hline 4 & Triggers the narrative & $\begin{array}{l}\text { Multiple goals, interests and } \\
\text { needs. }\end{array}$ & $\begin{array}{l}\text { Relational interactions, } \\
\text { praxis. }\end{array}$ \\
\hline 5 & $\begin{array}{l}\text { Interactions and } \\
\text { conflicts }\end{array}$ & $\begin{array}{l}\text { Unilateral vision: internal } \\
\text { and external } \\
\text { Risk management and } \\
\text { benefits: to the extent that } \\
\text { the range of interests can } \\
\text { be affected. }\end{array}$ & $\begin{array}{l}\text { Multidimensional vision: } \\
\text { micro and macro. } \\
\text { Relational tensions: the } \\
\text { practices can change the } \\
\text { dominant strategy. }\end{array}$ \\
\hline 6 & Context & $\begin{array}{l}\text { Specific, changeable. } \\
\text { Each stakeholder acts in } \\
\text { their universe, maybe } \\
\text { varying according to the } \\
\text { interests. }\end{array}$ & $\begin{array}{l}\text { Pluralistic: uncertainty and } \\
\text { ambiguity. } \\
\text { The environment is complex } \\
\text { and can be confrontational. }\end{array}$ \\
\hline 7 & $\begin{array}{l}\text { Polyphony and } \\
\text { equivocality }\end{array}$ & $\begin{array}{l}\text { Disturbing elements of the } \\
\text { status quo generating } \\
\text { permanences and changes. }\end{array}$ & $\begin{array}{l}\text { Elements are inherent to } \\
\text { social interactions that are } \\
\text { at the origin of permanence } \\
\text { and change. }\end{array}$ \\
\hline 8 & $\begin{array}{l}\text { Relation to other } \\
\text { groups and society }\end{array}$ & $\begin{array}{l}\text { Superior value generation, } \\
\text { by means of participation in } \\
\text { networks that lead to } \\
\text { improved quality of life for } \\
\text { humans and the } \\
\text { environment }\end{array}$ & $\begin{array}{l}\text { Strategizing, doing strategy } \\
\text { daily, in a dynamic tension } \\
\text { between micro, meso and } \\
\text { macro. Open strategy with } \\
\text { the participation of } \\
\text { distinguished practitioners. }\end{array}$ \\
\hline
\end{tabular}

Source: Elaborated by the authors

The narratives are the means by which these interactions occur. They are both the form and the content by which intentions are expressed and trigger actions and practices aimed at the fulfillment of their needs, desires and goals (Rese et al., 2017). This relationship can put the narratives, seen as strategies, on a collision course within and between groups of interest, which generates stresses, changes and permanences. In this research, the scenario where this plot develops is the deployment of mineral activity, which is presented below. 


\section{METHODOLOGICAL PROCEDURES}

This research presents elements that might place it in the interface of the radical interpretative and structuralist paradigms, hinting that the complexity of social structures and practices cannot be limited to a single perspective. Gioia and Pitre (1990) defend the possibility of a multiparadigmatic approach as a way to welcome theoretical differences and, through the recognition of these differences, better understand the organizational phenomena. From the perspective of the theory of strategy as practice, according to Rasche and Chia (2009), structuralism is based on the existence of codes that influence human action. These codes, which structure human action, are given objectively (by the dominant organization) and people do not even question their existence. In interpretivism, "subjects assign meaning to the world based on ambiguous experiences, pre-existing mental schemas that each individual has based on their previous experience" (Rasche \& Chia, 2009, p. 718).

In relation to the data, this research is characterized by a qualitative approach, an activity that places the viewer in the world, according to Denzin and Lincoln (1994). The research was developed in the municipality of Patrocínio, Minas Gerais, where there are a phosphate deposit and a mining plant. For a mining enterprise to be implemented, participatory procedures exist that must occur to ensure that all stakeholders can express themselves freely on the subject and expose and defend their interests. In this step, there are public hearings, events that, in general, rely on the participation of the interested individuals and groups, especially those who have an interest in understanding the impacts of this process and the potential changes in the interaction with their needs, intentions, goals, values and beliefs. The Public Hearings in the deployment process of the mining activity in Patrocínio are presented in Figure 5.1.

The documentary research and analysis of the narratives found in this source of data made it possible to identify the interest groups treated in this research as follows: 1. Educational institutions; 2. Representatives of the entrepreneur; 3. Environmental organizations; 4. Representatives of the residents of the region of deployment; 5. Representatives of public authorities; and, 6 . Representatives of the productive sector. These comprise the public researched in the field, by means of interviews. The documentary research was an essential step to identify these interest groups who worked and work in the deployment process of phosphate mining activity in the municipality of Patrocínio. 


\begin{tabular}{llc} 
& (Figure 5.1) \\
\multicolumn{1}{c}{ MINING PUBLIC HEARINGS IN PATROCÍNIO } \\
\hline \multicolumn{1}{c}{ Event } & \multicolumn{1}{c}{ Documents } & Date \\
\hline $\begin{array}{l}\text { A public hearing for Mining Complex } \\
\text { Installation Licensing }\end{array}$ & Written Record & October $31^{\text {st }}, 2001$ \\
\hline $\begin{array}{l}\text { Public hearing to discuss the } \\
\text { implementation of the Industrial Complex } \\
\text { of FOSFÉRTIL }\end{array}$ & Transcription and photos & November $18^{\text {th }}, 2009$ \\
\hline $\begin{array}{l}\text { Public hearing to change the Installation } \\
\text { Licensing (IL) }\end{array}$ & Recording and \\
\hline
\end{tabular}

Source: Research data elaborated by the authors

The document data were collected in the physical form in public bodies where they were deposited by relevant regulations (SUPRAM, CODEMA, Municipal Administration and Prosecutors of Patrocínio and Uberaba, City Council of Patrocínio). Documents were also collected with the entrepreneurial company, and at the head offices of the institutions representing the environment and the productive sector. Data collection were also carried out on press reports, in printed and electronic media, and in audio and video recordings of the hearings. Furthermore, semi-structured interviews were conducted with representatives of six groups of interests described in Figure 5.2.

\section{(Figure 5.2) \\ INTERVIEW PARTICIPANTS}

\begin{tabular}{lll}
\hline Interest Groups & \multicolumn{1}{c}{ Interviewee } & \multicolumn{1}{c}{ Justification } \\
\hline Education Group & Interviewee EDU & $\begin{array}{l}\text { Higher education institutions have excelled in } \\
\text { the participation of the audience. }\end{array}$ \\
\hline Entrepreneur Group & Interviewee EMP & $\begin{array}{l}\text { The convenience of having the representative of } \\
\text { the current entrepreneur (Mosaic, since 2016) } \\
\text { present and acting in the area of the mine. }\end{array}$ \\
\hline Environment Group & $\begin{array}{l}\text { Respondents in this group are made up of } \\
\text { Interviewee MAI } \\
\text { Interentatives of the ma2 } \\
\text { environmental organizations in the municipality } \\
\text { of Patrocínio }\end{array}$ \\
\hline
\end{tabular}




\section{(Figure 5.2 (conclusion)) \\ INTERVIEW PARTICIPANTS}

\begin{tabular}{lll}
\hline \multicolumn{1}{c}{ Interest Groups } & \multicolumn{1}{c}{ Interviewee } & \multicolumn{1}{c}{ Justification } \\
Residents Group & $\begin{array}{l}\text { Interviewee M01 } \\
\text { Interviewee M02 }\end{array}$ & $\begin{array}{l}\text { Respondents were identified in the Public Civil } \\
\text { investigation process monitoring the mining } \\
\text { deployment which is available in the Public } \\
\text { Ministry of the State of Minas Gerais }\end{array}$ \\
\hline Public Authority Group & $\begin{array}{ll}\text { Interviewee PP1 } \\
\text { Interviewee PP2 }\end{array}$ & $\begin{array}{l}\text { Respondents were selected according to the } \\
\text { historic participation in the deployment process } \\
\text { of mining activity }\end{array}$ \\
\hline $\begin{array}{l}\text { Productive Sector } \\
\text { Group }\end{array}$ & Interviewee SP1 & $\begin{array}{l}\text { Respondents selected are responsible for the } \\
\text { institutions that represent the productive sector } \\
\text { of Patrocínio }\end{array}$ \\
\hline
\end{tabular}

Source: Elaborated by the authors.

The interviews were conducted in January and February 2018. A topic guide was developed and used to direct the interviews with the respondents. The interviews were carried out face-to-face, according to the location indicated by the interviewees, which were their workplaces and residences. Due to the restriction of availability of some respondents, interviews with interviewee EMP and MO2 were conducted by phone. All the interviews were recorded and transcribed.

As for the documentary research, in total, 163 narratives were found and their rankings in this research are in Figure 5.3. The audios and videos refer to material produced by press agents or the stakeholders themselves, as a way to record their practices.

\section{(Figure 5.3)}

NARRATIVES ANALYZED IN THE RESEARCH

\begin{tabular}{ll}
\multicolumn{1}{c}{ Sources for research of narrative elements } & Quantity of narratives \\
\hline Audio and videos & 18 narratives \\
\hline Digital and printed documents & 39 narratives \\
\hline Digital and printed media manifestations & 93 narratives \\
\hline Photos & 13 narratives \\
\hline
\end{tabular}


Regarding the procedures of analysis of the results, the procedure of analysis of narrative research is a specific process that concerns life stories, the narrative in discursive forms, such as social stories (Jovchelovitch \& Bauer, 2002). Content and documents analysis have the same objectives (contribute to the understanding of a given phenomenon). In this way, the document analysis is inserted in the content analysis that "works with the message enabling inferences about this reality” (Bardin, 1977, p. 51).

\section{(Figure 5.4)}

SEARCH CATEGORIES: CHANGE, PERMANENCES AND TENSIONS

\begin{tabular}{|c|c|}
\hline $\begin{array}{l}\text { Research } \\
\text { categories }\end{array}$ & Definitions \\
\hline Changes & $\begin{array}{l}\text { The changes are adaptations that, from the perspective of Jarzabkowski } \\
\text { (2004), can go from small incremental changes to drastic changes in the } \\
\text { strategic practices of organizations. To Vaara et al. (2016) the actors of } \\
\text { organizations compete to establish a dominant narrative about the change, } \\
\text { but these dominant narratives can also change the trajectory of the } \\
\text { organization in the future and also of the people involved. }\end{array}$ \\
\hline Permanences & $\begin{array}{l}\text { The permanence and continuity of the strategic practices come from a } \\
\text { balance between the social and collective structures of organizations, } \\
\text { practitioners, and the activities that integrate them. From this relationship } \\
\text { emerges the strategic practice. The permanents are connected to the inertial } \\
\text { tendencies of strategic practices of the actors in interaction in micro and } \\
\text { macro contexts (Jarzabkowski, 2003; 2004). }\end{array}$ \\
\hline $\begin{array}{l}\text { Relational } \\
\text { tensions }\end{array}$ & $\begin{array}{l}\text { For this research, tensions are the conflicts that can be generated from } \\
\text { dialogue among the various groups when they interact, in defense of their } \\
\text { interests, seeking the satisfaction of their needs in pluralistic contexts } \\
\text { (Jarzabkowski et al., 2013; Hoon, 2007) and therefore need negotiation } \\
\text { (Bonnafous-Boucher \& Rendtorff, 2016). The main tension points are: } \\
\text { temporality, people, actions, certainties and contexts (Clandinin \& Connelly, } \\
\text { 2000). }\end{array}$ \\
\hline
\end{tabular}

Source: Research data elaborated by the authors

To Bardin (1977), it is necessary to create a ranking in categories of analysis that allows the classification of units of meaning that allow generating inferences and, if possible, applied to the set of information. In Figure 5.4, the categories of analysis and definitions of these categories are displayed according to the theoretical perspective of the research. 


\section{THE STAKEHOLDERS IN THE IMPLEMENTATION PROCESS OF THE PHOSPHATE MINERAL EXTRACTION}

As presented in the theoretical framework, stakeholders are defined as individuals or groups who can influence or be influenced in the interaction with the organization, extra and intra-organization while defending their goals and interests, according to Freeman (1984), Freeman et al. (2010), Savage et al. (1991) Mitchell et al. (1997) and Mainardes et al. (2012). Even the groups that don't recognize their influence in certain processes may suffer social, economic, environmental and cultural influences. The documented research identified the interest groups that were entered as subjects in each phase of the deployment process of phosphate mining in the town of Patrocínio, Minas Gerais.

According to Figure 6.1, these stakeholders acted with greater or lesser intensity along the stages of the deployment process of the mining activity, through their narratives, seen as strategic practices.

During the research, 55 institutions were identified with potential interests in relation to the implementation of mining activity in Patrocínio/ MG. However, the participation of these institutions was not found in the researched narratives so as to compose the research data. From that relevance, 21 stakeholders were filtered, whose participation were more expressive and the classification took place according to the positions assumed or assigned to these 21 organizations, institutions and individuals (residents) in interaction with other groups and with the phenomenon of mining (Figure 6.1).

Research showed that not all 21 stakeholders participated in every stage, as can be seen from Figure 6.1, be it because of the discontinuation of their activities ( 1 and 20) or exit from the mining sector (5, 6 and 7). Stakeholders 8 and 9 shared control of the mineral extraction activity due to the moment of transition of ownership of mining rights, the sale of assets of Vale Fertilizantes to Mosaic (2016). Only two members classified as public authorities (DNPM) and entrepreneurs CVFT and CVRD participated in the research phase that took place from 1969 to 2003, in Figure 6.1. One can also observe that representatives of public authorities, residents and the environment had more consistent and permanent participation during the phases of planning, implementation and operation (2003 to 2017). 


\section{(Figure 6.1)}

\section{INTEREST GROUPS IN THE PHASES OF IMPLEMENTATION OF PHOSPHATE MINING ACTIVITIES IN PATROCÍNIO}

\begin{tabular}{|c|c|c|c|c|c|c|}
\hline No. & $\begin{array}{l}\text { Institution - Organization - } \\
\text { Individuals }\end{array}$ & Classification & $\begin{array}{l}\text { Research } \\
\text { phase }\end{array}$ & $\begin{array}{l}\text { Planning } \\
\text { phase }\end{array}$ & $\begin{array}{l}\text { Implementation } \\
\text { phase }\end{array}$ & $\begin{array}{l}\text { Operation } \\
\text { phase }\end{array}$ \\
\hline 1 & IESP & Education & & & & \\
\hline 2 & IFTM & Education & & & & \\
\hline 3 & SENAI & Education & & & & \\
\hline 4 & UNICERP & Education & & & & \\
\hline 5 & CVFT & Entrepreneur & & & & \\
\hline 6 & CVRD & Entrepreneur & & & & \\
\hline 7 & FOSFÉRTIL & Entrepreneur & & & & \\
\hline 8 & Mosaic & Entrepreneur & & & & \\
\hline 9 & Vale Fertilizantes & Entrepreneur & & & & \\
\hline 10 & CERVIVO & Environment & & & & \\
\hline 11 & CODEMA & Environment & & & & \\
\hline 12 & FONASC & Environment & & & & \\
\hline 13 & Affected residents & Residents & & & & \\
\hline 14 & DNPM & $\begin{array}{l}\text { Public } \\
\text { Authority }\end{array}$ & & & & \\
\hline 15 & State Public Ministry & $\begin{array}{l}\text { Public } \\
\text { Authority }\end{array}$ & & & & \\
\hline 16 & Federal Public Ministry & $\begin{array}{l}\text { Public } \\
\text { Authority }\end{array}$ & & & & \\
\hline 17 & City Hall & $\begin{array}{l}\text { Public } \\
\text { Authority }\end{array}$ & & & & \\
\hline 18 & SUPRAM & $\begin{array}{l}\text { Public } \\
\text { Authority }\end{array}$ & & & & \\
\hline 19 & ACIP/CDL & $\begin{array}{l}\text { Productive } \\
\text { sector }\end{array}$ & & & & \\
\hline 20 & ADP & $\begin{array}{l}\text { Productive } \\
\text { sector }\end{array}$ & & & & \\
\hline 21 & Hospital Santa Casa & $\begin{array}{l}\text { Productive } \\
\text { sector }\end{array}$ & & & & \\
\hline
\end{tabular}

Source: Elaborated by the authors. 
Figure 6.2 was compiled from the document research of the public hearings, which shows the locus of the formal interactions of these groups in defense of their interests. For the present research, public hearings were a formal platform for the narratives of groups and interests that allowed the identification of six groups of interest. Figure 1 represents the embedded network of groups in interest in interaction with others and with the phenomenon of mining. The phenomenon of mining occupies the central position from the interaction and intra and intergroup practices that unfold in actions sometimes in cooperation, in competition or in collaboration.

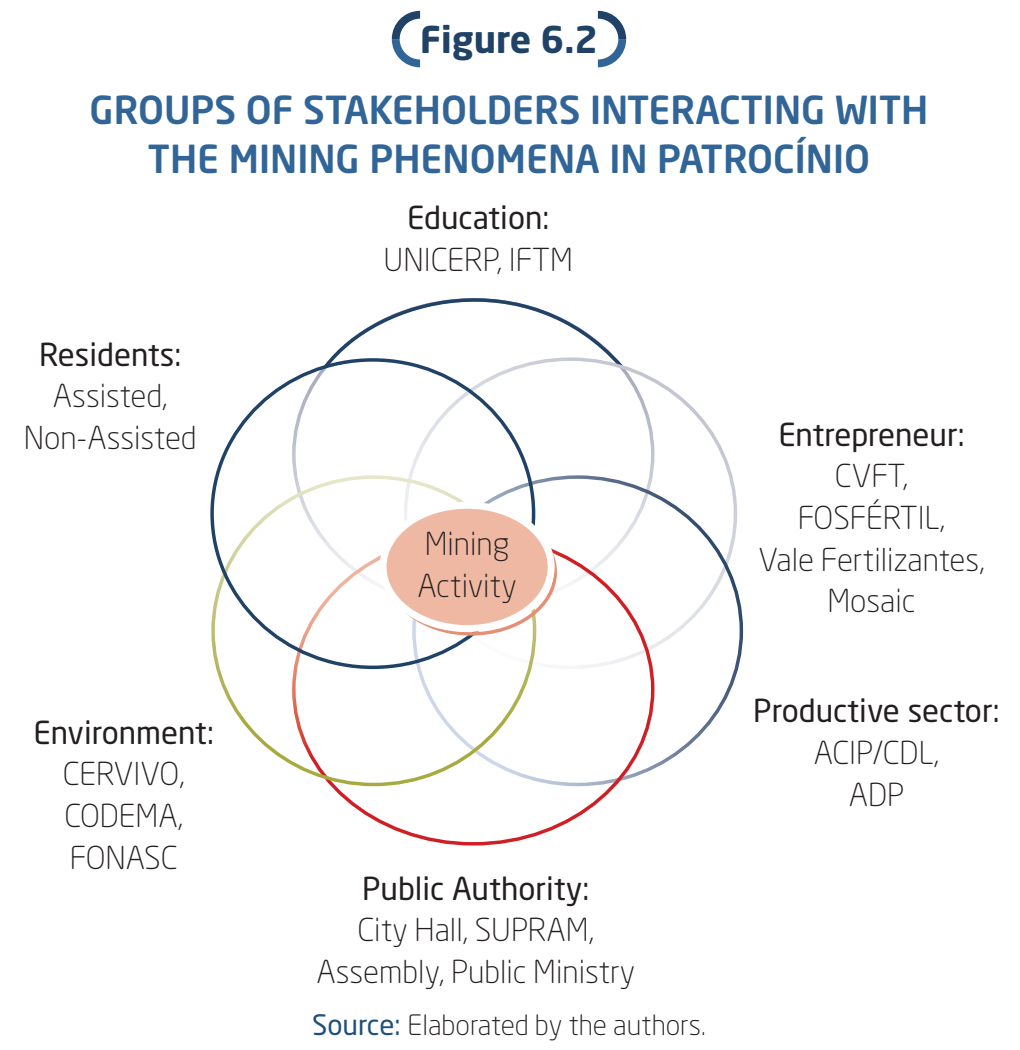

\section{NARRATIVES SEEN AS STRATEGIC PRACTICES: STRESSES, CHANGES AND PERMANENCES}

The analysis of the narratives of the interest groups, seen as strategic practices over the four phases of implementation of the phosphate mining activity in Patrocínio, allows the observation of the generation of tensions, 
permanences and changes. The results lead to the identification of potential tension generators for each group of stakeholders, in a total of 21 , as seen in Figure 7.1. These tension-generating potentials are mediated by the attributes of narratives: pluralistic contexts, power, conflict, ambiguity, polyphony and equivocality, networks, mutuality and open strategy (Figure 4.1). In this way, changes and permanency in the strategies as practices are identified for each group of stakeholders.

The pluralistic contexts that affect organizations, through the praxis of their practitioners, be it for strategizing or organizing, are recognized by Jarzabkowski and Fenton (2006), Denis et al. (2007), Jarzabkowski et al. (2013). In pluralistic contexts, organizations are exposed to a wide range of interests and objectives due to the coexistence of a large number of groups. In these contexts, the power is dispersed and the groups that exert most influence can achieve their goals more efficiently. Group diversity generates conflicts to establish dominant practices, with the prevalence of self-interest. Possible conflicts, in the form of tensions, in the context of research, spark change and permanence.

Ambiguity and clarity counterbalance each other in the field of strategy as practice, because they allow fluctuation of the levels of power and decision-making of the interlocutors (McCabe, 2009). However, neither clarity nor ambiguity is effective without their acceptance. To Pascucci and Meyer (2013), in pluralistic contexts, ambiguity and the difficulty of consensus press organizing and strategizing creating tensions that, in turn, lead to permanent or changes.

Polyphony and equivocality are dialogical attributes present in the narrative. Polyphony refers to the dissonance in the understanding and dissemination of the key strategies of the organization. Equivocality is considered as the ability to generate misunderstandings in complex relationships generated by strategy as practice in pluralistic environments (Brown \& Thompson, 2013; Vaara et al., 2016).

Mutuality is a perspective supported by Sachs and Rühli (2011) for the stakeholders that operate in networks, potentializing the benefits for those involved and minimizing the risks of failure. Networks are perceived as the tissue in which the interested parties are related to the generation of higher values. The network perspective is also analyzed by Bonnafous-Boucher and Rendtorff (2016), who adopt a political approach of stakeholder theory interfacing with strategy, allowing the practitioners recognition of those involved as well as their needs. These positions are harmonized with the open perspective of a generation of strategy as practice, which accommodates the experiences and interactions between practitioners, seeking transparency 
and inclusion, involving internal and external stakeholders, at micro and macro levels (Hautz et al., 2016).

The narratives identified, classified and analyzed were referenced to each group of stakeholders, as shown in Figure 7.1. These groups were assigned the narratives identified in the research.

(Figure 7.1)

TENSIONS, PERMANENCES AND CHANGES

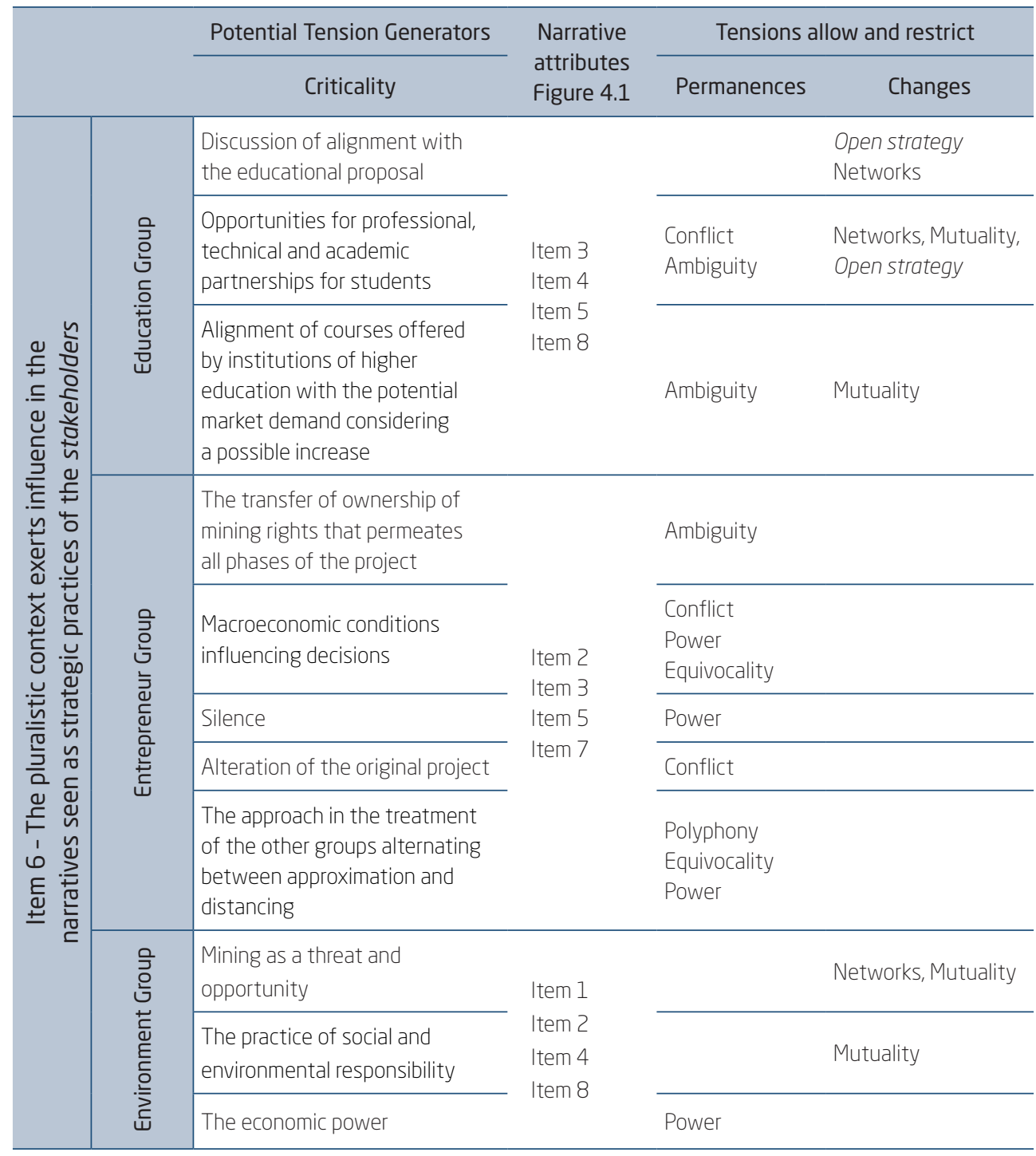

(continue) 


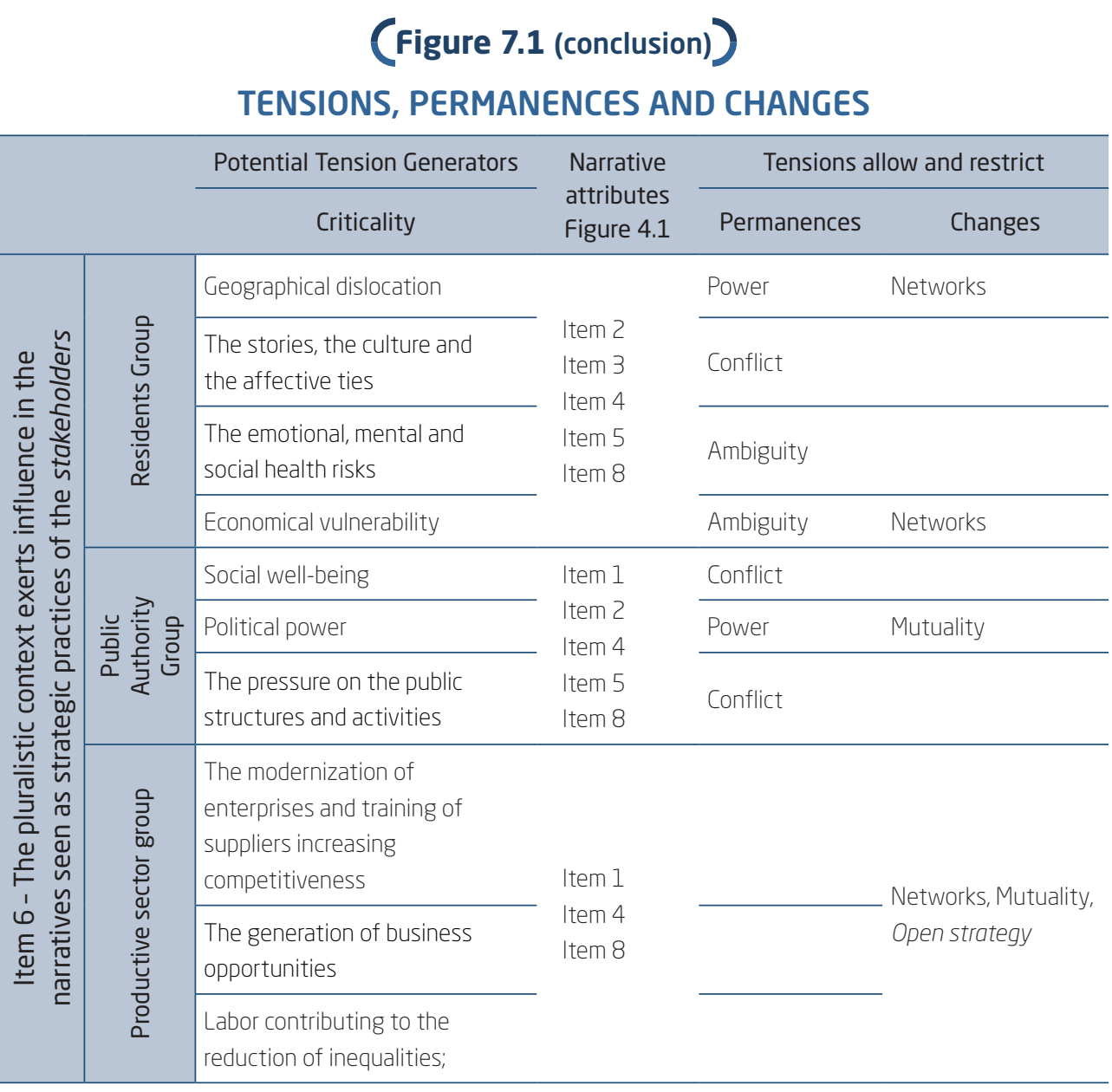

Source: Elaborated by the authors.

These narratives show elements with the potential to generate tensions for each group to act and interact in the pursuit of achieving their own goals, fulfilling their needs and satisfying their interests.

\section{CONCLUSIONS AND IMPLICATIONS OF THE RESEARCH}

This paper moved on towards a political perspective of stakeholders, which converses with strategy as practice, and generates opportunities for studies that give emphasis to networks of stakeholders and mutual and higher value creation from the idea of open strategy, considering the porosity of organizations and the role of a society of stakeholders. Both studies bring 
freshness to the study of strategy, giving it a postmodern perspective and a political and social approach, providing a link between strategy as practice and a political perspective of stakeholders through narratives. This extends the complexity of research, because it ultimately puts the research on interfaces between interpretive and structuralist ontological and epistemological assumptions, which consider the point of view of the individuals, their interests, needs, goals and also the power relations that are built for those individuals, groups and institutions in their everyday intra and inter-organizational interactions.

The research of the narratives of the stakeholders showed the presence of twenty-one participants distributed in six groups, according to their interests, which showed similarities with regard to the phenomenon of mining. The design of the research considers the relationship of these stakeholders and practitioners with a phenomenon - the implementation process of a phosphate mining plant in the city of Patrocínio - and the results showed the proposed theoretical linkage. Field research showed that the groups alternate their interaction with other groups and with the phenomenon in case, sometimes adopting a reactive position, getting involved only when they are stimulated. Organizations and institutions also discontinued their activities or discontinued their interest, or simply were not present in relevant moments as in the case of public hearings about the implementation of the mining activities.

Field research showed a total of 163 narratives analyzed, seen as strategic practices of interest groups and practitioners along the phases of deployment. Narratives are social constructions capable of generating tensions, permanence or change in organizations, and these were synthesized at the end of the analysis of the results. The actors/practitioners compete for a dominant narrative that can change the future of organizations and of the phenomenon of mining, and also their future as individuals. This context raises tensions; more than the needs, goals or intentions of groups, it is the tensions that trigger the narratives of change and permanence. In this sense, the needs, goals and intentions seem to be in the background. They are subjugated by the risk that needs will not be satisfied or that the goals will not be achieved or intentions will not translate into actions, in the end, that strategic practices will not be carried out, if the interests of the other group offer risks of exclusion or competition for benefits.

The context in which the narratives are produced impacts the phenomenon by means of lobbying in interaction. The interaction of groups with the phenomenon of mining, researched from the narratives of these 
practitioners, showed that the opening movement of strategy (open strategy), which encourages transparency and inclusion, requires the study of stakeholders and their performance at different levels (intra and interorganizations, micro and macro levels) in the construction of strategy.

The limitations of this research are reflected in: 1. Not all interest groups were included as research audience, since the inclusion of all stakeholders could allow greater understanding of the phenomenon researched; 2 . Because it is a dynamic interaction process, the narratives should be presented to the reader, but at the same time, there was a need to limit the exposure of the ample material researched, this could help improve the understanding of the contextual scope.

For future research, we recommend the study of mining activities in other localities, as regionalism, or peculiarities of the mining sector that are distinct and studies in other regions that will broaden the understanding of narrative practices of stakeholders in this activity. Also, we recommend future studies on the dialogue between a political perspective of stakeholders and the perspective of strategy as practice. The study of the practices of those who practice strategy, in addition to their economic interests, can enlarge the knowledge in the field of organizational strategy, opening up new vistas.

\section{AS NARRATIVAS DOS STAKEHOLDERS SOB A PERSPECTIVA DA ESTRATÉGIA COMO PRÁTICA SOCIAL}

\section{$\int$ RESUMO}

Objetivo: O artigo é conduzido pela seguinte questão: “Como as narrativas de grupos de interesses contribuem para o diálogo entre a perspectiva da estratégia como prática e a teoria dos stakeholders?”. O objetivo é analisar as mudanças, permanências e tensões nas narrativas dos stakeholders, vistas como práticas estratégicas, no contexto da mineração. Originalidade/valor: A estratégia como uma prática social diz respeito às relações entre organizações, indivíduos e sociedade em busca de coexistência. Este estudo estabelece um diálogo entre a estratégia como prática social e uma perspectiva política dos stakeholders, considerando que interagem em redes, buscando a criação de valor a partir da mutualidade. 
Design/metodologia/abordagem: A pesquisa de campo foi conduzida numa abordagem qualitativa e longitudinal. A coleta de dados utilizou técnicas de pesquisa documental em atas e vídeos de audiências públicas, pesquisa em jornal e realização de entrevistas.

Resultados: Os resultados mostram interações narrativas de seis grupos de interesse: organizações empreendedoras, Poder Público, educação, meio ambiente, moradores da área de implantação e setor produtivo. $\mathrm{O}$ resultado sugere um papel de relevância das tensões relacionais como elementos que restringem e possibilitam as mudanças e permanências e evidenciam a natureza dinâmica das interações intra e intergrupos de stakeholders. O diálogo teórico proposto amplia o campo dos estudos da estratégia, em uma vertente pós-moderna, ao estabelecer um diálogo com uma vertente política da ação dos stakeholders, como alternativa a uma perspectiva funcionalista tradicional no campo.

\section{$\int$ PALAVRAS-CHAVE}

Estratégia como prática. Teoria dos stakeholders. Pesquisa narrativa. Setor de mineração. Tensão relacional.

\section{REFERENCES}

Bardin, L. (1977). Análise de conteúdo. São Paulo, SP: Edições 70.

Barros, A., \& de Pádua Carrieri, A. (2015). O cotidiano e a história: construindo novos olhares na Administração. Revista de Administração de Empresas, 55(2). doi:10.1590/S0034-759020150205

Bonnafous-Boucher, M., \& Rendtorff, J. D. (2016). Stakeholder theory: A model for strategic management. CIDADE: Springer International Publishing. doi:10.1007/978-3-319-44356-0

Bridoux, F., \& Stoelhorst, J. W. (2014). Microfoundations for stakeholder theory: Managing stakeholders with heterogeneous motives. Strategic Management Journal, 35(1), 107-125 doi:10.1002/smj.2089

Brown, A. D., \& Thompson, E. R. (2013). A narrative approach to strategyas-practice. Business History, 55(7), 1143-1167. doi:10.1080/00076791.20 13.838031 
Chia, R., \& MacKay, B. (2007). Post-processual challenges for the emerging strategy-as-practice perspective: Discovering strategy in the logic of practice.Human Relations, 60(1),217-242. doi:10.1177/0018726707075291

Chia, R., \& Rasche, A. (2010). Epistemological alternatives for researching strategy as practice: building and dwelling worldviews. Cambridge handbook of strategy as practice (pp. 34-46). doi:10.1017/CBO9780511777882.003

Clandinin, D. J., \& Connelly, F. M. (2000). Narrative inquiry: Experience and story in qualitative research.

Clarkson, M. E. (1995). A stakeholder framework for analyzing and evaluating corporate social performance. Academy of Management Review, 20(1), 92-117. doi:10.5465/amr.1995.9503271994

Czarniawska, B. (2007). Narrative inquiry in and about organizations. Handbook of narrative inquiry: Mapping a methodology (pp. 383-404). doi:10.4135/9781452226552.n15

Denis, J. L., Langley, A., \& Rouleau, L. (2007). Strategizing in pluralistic contexts: Rethinking theoretical frames. Human Relations, 60(1), 179-215. doi: $10.1177 / 0018726707075288$

Denzin, N. K., \& Lincoln, Y. S. (1994). Handbook of qualitative research. CIDADE: Sage.

Dias, A. T. B. B. B., Rossetto, C. R., \& Marinho, S. V. (2017). Estratégia como Prática Social: um Estudo de Práticas Discursivas no Fazer Estratégia. Revista de Administração Contemporânea, 21 (3), 393-412. doi:10.1590/ 1982-7849rac2017160095

Donaldson, T., \& Preston, L. E. (1995). The stakeholder theory of the corporation: Concepts, evidence, and implications. Academy of Management Review, 20(1), 65-91. doi:10.5465/amr.1995.9503271992

Fenton, C., \& Langley, A. (2011). Strategy as practice and the narrative turn. Organization Studies, 32(9), 1171-1196. doi:10.1177/0170840611410838

Freeman, R. E. (1984). Strategic Management: A Stakeholder Approach. Boston, MA: Pitman.

Freeman, R. E., Harrison, J. S., Wicks, A. C., Parmar, B. L., \& De Colle, S. (2010). Stakeholder theory: The state of the art. Cambridge University Press. doi:10.1017/CBO9780511815768

Gioia, D. A., \& Pitre, E. (1990). Multiparadigm perspectives on theory building. Academy of Management Review, 15(4), 584-602. doi:10.5465/ amr.1990.4310758 
Hautz, J., Seidl, D., \& Whittington, R. (2017). Open strategy: Dimensions, dilemmas, dynamics. Long Range Planning, 50(3), 298-309. doi:10.1016/j. lrp.2016.12.001

Hoon, C. (2007). Committees as strategic practice: The role of strategic conversation in a public administration. Human Relations, 60(6), 921-952. doi:10.1177/0018726707080081

Jarzabkowski, P. (2003). Strategic practices: An activity theory perspective on continuity and change. Journal of Management Studies, 40(1), 23-55. doi:10.1111/1467-6486.t01-1-00003

Jarzabkowski, P. (2004). Strategy as practice: recursiveness, adaptation, and practices-in-use. Organization Studies, 25(4), 529-560. doi:10.1177/017 0840604040675

Jarzabkowski, P., \& Fenton, E. (2006). Strategizing and organizing in pluralistic contexts. Long Range Planning, 39(6), 631-648. doi:10.1016/j. lrp.2006.11.002

Jarzabkowski, P., Lê, J. K., \& Van de Ven, A. H. (2013). Responding to competing strategic demands: How organizing, belonging, and performing paradoxes coevolve. Strategic Organization, 11(3), 245-280. doi:10.1177/ 1476127013481016

Jarzabkowski, P., \& Paul Spee, A. (2009). Strategy as practice: A review and future directions for the field. International Journal of Management Reviews, 11 (1), 69-95. doi:10.1111/j.1468-2370.2008.00250.x

Johnson, G., Melin, L., \& Whittington, R. (2003). Micro strategy and strategizing: towards an activity based view. Journal of management studies, 40(1), 3-22. doi:10.1111/1467-6486.t01-2-00002

Jones, T. M., \& Wicks, A. C. (1999). Convergent stakeholder theory. Academy of Management Review, 24(2), 206-221. doi:10.5465/amr.1999.1893929

Jovchelovitch, S., \& Bauer, M. W. (2002). Entrevista narrativa. Pesquisa qualitativa com texto, imagem e som: um manual prático, 4, 90-113.

Luz, C. L. M., \& Walter, S. A. (2016). Explorando as bases conceituais de estudos de Richard Whittington e de Paula Jarzabkowski relacionadas à estratégia como prática. Revista Unifeso-Humanas e Sociais, 2(02), 168-193

Mainardes, E., Alves, H., \& Raposo, M. (2012). A model for stakeholder classification and stakeholder relationships. Management Decision, 50(10), 1861-1879. doi:10.1108/00251741211279648

McCabe, D. (2009). Strategy-as-power: Ambiguity, contradiction and the exercise of power in a UK building society. Organization, 17(2), 151-175. doi:10.1177/1350508409338885 
Mitchell, R. K., Agle, B. R., \& Wood, D. J. (1997). Toward a theory of stakeholder identification and salience: Defining the principle of who and what really counts. Academy of Management Review, 22(4), 853-886. doi:10.5465/amr.1997.9711022105

Oliveira, S. A., \& Bulgacov, Y. L. M. (2013). Wittgenstein e a Administração: Potencialidades Explicativas da Pragmática da Linguagem aos Estudos Organizacionais e Estratégia. Revista de Administração Contemporânea, 17(5). doi:10.1590/S1415-65552013000500004

Pascucci, L., \& Meyer Jr, V. (2013). Estratégia em contextos complexos e pluralísticos. Revista de Administração Contemporânea, 17(5). doi:10.1590/ S1415-65552013000500003

Rasche, A., \& Chia, R. (2009). Researching strategy practices: A genealogical social theory perspective. Organization Studies, 30(7), 713-734. doi:10.11 77/0170840609104809

Rese, N., Kuabara, F. H. S., Villar, E.G., \& Ferreira, J.M. (2017). O Vir a Ser da Estratégia como uma Prática Social. Revista de Administração Contemporânea, 21 (2). doi:10.1590/1982-7849rac2017150300

Sachs, S., \& Rühli, E. (2011). Stakeholders matter: A new paradigm for strategy in society. CIDADE: Cambridge University Press. doi:10.1017/CBO978 1139026963

Savage, G. T., Nix, T. W., Whitehead, C. J., \& Blair, J. D. (1991). Strategies for assessing and managing organizational stakeholders. The Executive, 5(2), 61-75. doi:10.5465/ame.1991.4274682

Walter, S. A., \& Augusto, P. O. M. (2011). A institucionalização da estratégia como prática nos estudos organizacionais. Revista de Administração, 46(4), 392-406. doi:10.5700/rausp1019

Whittington, R. (1996). Strategy as practice. Long Range Planning, 29(5), 731-735. doi:10.1016/0024-6301(96)00068-4

Whittington, R. (2003). The work of strategizing and organizing: for a practice perspective. Strategic Organization, 1(1), 117-125. doi:10.1177/14 7612700311006

Whittington, R. (2006). Completing the practice turn in strategy research. Organization Studies, 27(5), 613-634.

Wilson, D. C., \& Jarzabkowski, P. (2004). Thinking and acting strategically: New challenges for interrogating strategy. European Management Review, 1(1), 14-20. doi:10.1057/palgrave.emr.1500008 


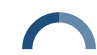

José B. S. Neto, Jacquelaine F. Borges

\section{AUTHOR NOTES}

José Batista de S. Neto, Programa de Pós-Graduação em Administração (PPGA), Universidade Federal de Uberlândia (UFU); \& Jacquelaine Florindo Borges, Faculdade de Economia, Administração e Contabilidade (FEA), Universidade de São Paulo (USP).

José Batista de S. Neto is now Ph.D student at Faculdade de Economia, Administração e Contabilidade - Ribeirão Preto, Universidade de São Paulo; \& Jacquelaine Florindo Borges is now Professor at Faculdade de Gestão e Negócios (FAGEN), Universidade Federal de Uberlândia (UFU).

Correspondence concerning this article should be addressed to José Batista de S. Neto, Rua Joaquim Carlos dos Santos, 788, Nossa Senhora de Fátima, Patrocínio, Minas Gerais, Brazil, CEP: $38744-535$.

E-mail: joseneto@ufu.br

\section{EDITORIAL BOARD}

Editors-in-chief

Janette Brunstein

Silvio Popadiuk

Associated Editor

Thais Vick

Technical Support

Vitória Batista Santos Silva

\section{EDITORIAL PRODUCTION}

Publishing Coordination

Irina Migliari

Layout Designer

Copyeditor

Irina Migliari (English)

Emap

Graphic Designer

Libro
Language Editor

Daniel de Almeida Leão (English)

Irina Migliari (Portuguese) 